\title{
Economic growth and unemployment issue: Panel data analysis in Eastern European Countries
}

\author{
Özgür Bayram Soylu \\ Department of Economics, Hacettepe University, \\ Turkey \\ soylu@hacettepe.edu.tr \\ İsmail Çakmak \\ Department of Economics, Hacettepe University, \\ Turkey \\ ismailcakmak@bacettepe.edu.tr

\section{Fatih Okur} \\ Department of Economics, Hacettepe University, \\ Turkey \\ fatih.okr@bacettepe.edu.tr
}

Abstract. The concepts of economic growth and unemployment are at the beginning of the most important variables in the sense that all economies are choosing and implementing economic policies. The purpose of this study to investigate the relation between economic growth and unemployment in Eastern European Countries for the period of 1992-2014 within panel data framework. In this paper this relationship has been examined in the context of Okun's Law. Panel Unit Root, Pooled Panel OLS and Panel Johansen Co-integration tests are applied respectively. The results show that the economic growth and unemployment series are stationary at first level, unemployment affected positively by economic growth, in other words 1\% rise in GDP will fall the unemployment rate by $0.08 \%$ because of Okun's coefficient for Eastern European Countries and there is a co-integration between these important macroeconomic variables.

Keywords: Okun's law, panel cointegration, unemployment, GDP, Eastern European Countries.

JEL Classification: E10, E24, O47, O52 


\section{INTRODUCTION}

Reducing unemployment and achieving a high rate of economic growth are the most important priorities of developed and developing country economies. In terms of the success of a country's economy, economic growth and employment are two extremely important macroeconomic variables and are indispensable elements of the economic policies of many countries, especially developed countries.

Economic growth, an indicator of welfare of a country, is measured by GNP or its per capita value. In most macroeconomic books, the concept of economic growth is defined as the increase in the amount of goods and services produced in a country during by the time of progress. If we consider that there are many countries with different economic sizes all over the world, we can see that some of these countries are very rich, some are very poor, and a great majority is among these two extremes. Some of these countries are growing very fast, but some countries are either too slow or not growing at all. For this reason, researching the reasons for these differences in growth between countries and examining the concept of economic growth has become the focus of attention.

Another macroeconomic variable that is an important as economic growth and which is of particular concern to countries is unemployment. Unemployment represents the level of employment in which people have the desire and ability to work and want to pay but who cannot find jobs. Unemployment arises from the economic structure of a country, and it arises from different reasons depending on whether it is a developed or underdeveloped country. The reason for unemployment in underdeveloped countries is capital inadequacy, while in developed countries technological progress is the reason (Yilmaz, 2005)

In this study we will examine the relation between the two important macroeconomic variables of economics in the context of Eastern European Countries which is chosen.

In our study, the first part described the concepts of unemployment. In the second part, growth theories are discussed. In the third part, the framework of the Okun's Law is revealed. In the fourth part of the study, there are studies presenting the relation between economic growth and unemployment. In the following sections, data, methodology and empirical results are presented. The final section is devoted to a general evaluation of the study results.

\section{CONCEPTS OF ECONOMIC GROWTH AND UNEMPLOYMENT}

Unemployment is the presence of a workforce in and out of the working force who is willing to work from the current wage and cannot find a job. Types of unemployment can be defined as voluntary unemployment, involuntary unemployment, frictional unemployment, cyclical unemployment, seasonal unemployment, technological unemployment, structural unemployment and hidden unemployment. These types of unemployment are defined as follows:

- Voluntary unemployment: It is the unemployment of individuals who are looking for higher wages and better jobs that do not want to work at the current wage level.

- Involuntary unemployment: It is the unemployment of people who are ready to work at current wage level and who cannot find work.

- Frictional unemployment: It is the type of unemployment determined during the change of place and occupation. Fractional unemployment can arise even when the economy is in full employment.

- Cyclical unemployment: It is the unemployment created by the shrinkage that occasionally arises in the production volume. In other words, it is the result of the fact that the effective demand of economy is low compared to the production volume. This type of unemployment is caused by the fact that the economic life and activities do not always continue at the same level and fluctuate. 
- Seasonal unemployment: It is the unemployment of people who work during certain periods of the year and are unemployed during certain periods. In sectors such as tourism, construction and agriculture, the level of production and hence the unemployment rate fluctuate seasonally. Seasonal unemployment is most apparent in the agricultural sector. In developed and advanced industrial countries, seasonal unemployment is often due to changes in the demand for goods.

- Technological unemployment: It is the result of using machines instead of labor force. This type of unemployment occurs with technological progress in countries or innovation in enterprises and technological changes in production.

- Structural unemployment : It is the type of unemployment that arises during periods when the economy is at a collective and constantly stagnant level with all sectors. Structural unemployment can also be defined as the mismatch between the general structure of labor demand, acting on factors such as labor force structure, geographical differences, occupation, skill and industry.

- Hidden unemployment: It is the unemployment that people who participate in the production process do not have any contribution to production, that is, those whose marginal productivity is zero.

The increase in the amount of goods and services produced in a country over time is called economic growth. Growth in terms of income per capita means both an increase in the size of economic activities in a society and an increase in per capita income.

It would be useful to discuss growth theories before debate the literature on economic growth and unemployment.

\section{THEORY OF GROWTH}

One of the most important indicators of the increase in the level of economic and social welfare of a country, the phenomenon of economic growth is a constant debate on economists. Growth theories explain the factors that determine the rate of economic growth in a country. On the other hand, growth theories explain the reasons for differences in income and growth rates among countries.

The main topic of the mercantilist era on which the economy and the state grow together is foreign trade. Mercantilism focuses on the desire to have precious metals and foreign trade issues. Although mercantilism differs from country to country, it is nationalistic and interventional everywhere.

The physiocrats state that the only producer industry in the economy is agriculture. They claim that it is the only way to grow because it gives more than the spending. According to physiocrats agriculture is the main source of economic growth. A doctrine that focuses on the direction of the economy's supply.

The ideas the physiocrats advocate set the stage for the birth of classical thought. The most important representatives of classical economics are A. Smith, D. Ricardo and T. Malthus. The "Classical Growth Theory" accepts that wages are determined at the natural market wage level. Classical economists acknowledge that the economy will enter a recession phase where it will not grow constantly. While Adam Smith has argued that this process is not a negative situation, Robert Malthus and David Ricardo describe it as a negative situation. According to Robert Malthus and David Ricardo, the stagnation that will be experienced during the growth period is a very negative situation.

Ricardo has examined how national income is distributed among the factors of production. Schumpeter is known as the first economist to argue that technological development will have positive effects on economic growth. In Schumpeter's approach, technology is an external concept as it is in the same neoclassical approach, and the firms follow the technological innovations and buy the technology that suits them. Schumpeter refers to innovation as an endless source of growth. 
In the socialist system based on Marx, a large part of the means of production used in production is in state ownership. According to theory, there is an excess of labor supply in the labor market outside extraordinary circumstances, and the capitalist system itself produces unemployment.

Harrod-Domar model is basically based on the study of Solow (1956). Economic growth depends on the net increase in capital stock. The growth rate is determined by the capital / product ratio and the saving rate used to measure the relationship between production in an economy and capital stock. Harrod and Domar have tried to explain how the country's economies can grow in balance and how this growth can be sustained. It is difficult to calculate the concepts used in the models where both Harrod and Domar are built. In both models, the capital was shown as a factor in increasing production. The effects of labor and technological development on production have been neglected. The Harrod-Domar growth model, which explains the rate of growth by the marginal saving rate (s) and the capital-output coefficient $(\mathrm{k})$, is the link between total demand, production and employment.

$$
\Delta \mathrm{Y} / \mathrm{Y}=\mathrm{y} / \mathrm{s}
$$

The neoclassical model does not have a clear role to play in the politics it applies, since there is no transfer mechanism that allows for growth relations with policy implementations in such a structure that accepts technological change externally with population growth (Shaw 1992, p. 611). The neoclassical growth model has sought to find solutions to the questions of why some countries are rich, others are poor and how permanent growth in the economy will take place. The model explains in response to the first question that some countries invest more and have fewer population increases. The answer to the second question is technological development. Solow has examined the effects of savings, population growth and technological development on growth and their impact on each other. The main reason why the Solow model is called neoclassical growth model is that it is based on neoclassical thought. The model considers an economy that produces and consumes homogeneous single goods. This means that there is a closed economy. Savings and investment rates are equal and law of diminishing returns is valid. Full competition and full employment conditions dominate the market. The constant returns to scale are production function. Finally, the technology is external.

Endogenous growth model emphasizing that economic growth must be sought in the system. The theory called "endogenous growth theory" by Romer has been developed against neoclassical growth theory (Romer, 1986). Also, technological development is intrinsic and influenced by economic decisions. According to endogenous growth theory, the state needs to intervene in the economy in order to achieve the optimal growth rate. Technological development in the model is endogenous. The underlying theory of endogenous growth, as laid down by Romer (1986) and Lucas (1988), is that the economic growth is in the neoclassical model, as opposed to external technological developments that are not under the control of the market mechanism,the economic forces operating within it (Ercan, 2000). In this model information is a secret public property.

There are different approaches within the Endogenous Growth Theories. AK Growth Model is the first of these. The AK model assumes that there is a linear relationship between total output $(\mathrm{Y})$ and capital $(\mathrm{K})$. The AK model production function is as follows:

$$
\mathrm{Y}=\mathrm{AK}
$$

The second model is the "Arrow Romer Model". The basis of the Romer model lies in the "learning by doing" view proposed by Arrow (1962). In Romer's model, the production function is to increase the labor force of firms. 
The third model is the "Lucas Model". According to Lucas, human capital is defined as the sum of the knowledge and skills that are made by learning investments made by the labor force and by learning.

The fourth model is the R \& D model. According to Romer, the source of growth is technological development. For this reason, he tried to explain the relation between economic growth and technological development.

\section{OKUN'S LAW}

Okun (1962), in his study of the US economy, empirically proved the inverse relationship between the unemployment rate and the potential output, depending on the participation in the workforce, the duration of work and the change in productivity (Holmes and Silverstone, 2006).

The theoretical ground of the relations Okun investigated is based on the fact that the increased workforce must produce more goods and services. Arthur Okun found that the unemployment rate declined in the years when the real growth rate was high, whereas the unemployment rate increased in the years when the real growth rate remained low or even negative.

How the unemployment rate will be affected if the actual decedent deviates from its potential output is stated as follows (Guran, 1999):

$$
\mathrm{u}=\mathrm{u}^{*}-\left[\beta\left(\mathrm{y}-\mathrm{y}^{*}\right) / \mathrm{y}^{*}\right]
$$

$\mathrm{u}$ represents actual unemployment rate, $\mathrm{u}^{*}$ represents natural unemployment rate, $\mathrm{y}$ represents actual real income, $y^{*}$ represents potential real income. Okun estimated the $\beta$ coefficient for the US economy for the period 1947-1960 as approximately 0.3 . Accordingly, when the actual output is greater than $1 \%$ of the potential output, the actual unemployment rate will be less than $0.3 \%$ of the natural unemployment rate.

\section{LITERATURE}

This study investigated the relationship between growth and unemployment in Eastern European countries When the literature is examined, it is seen that similar studies are not encountered; it is possible to say that this study will contribute to the literature.

Some of the studies explaining the relationship between growth and unemployment rates are presented below in chronological order.

The Okun's Law (Okun, 1963) is an economic model that reflects the relationship between unemployment and economic growth. He examines the growth and unemployment figures for the US economy, finds that the unemployment rate falls in the years when the real growth rate is high, whereas the unemployment rate has risen in the years when the real growth rate has remained low or even negative.

Okun (Okun, 1963) modelled economic growth and unemployment relationship as follows:

$$
\Delta \mathrm{u}=-0.5 *(-2.25)
$$

More clearly; in the years when the average annual real growth rate of the period of 1948-1960 exceeded $2.25 \%$, every $1 \%$ economic growth above $2.25 \%$ reduced the unemployment rate by 0.5 .

For the following periods, the number of studies investigating this relationship using different methods has increased in order to get the Okun's coefficient.

Evans (1989) studied the US economy for the period 1950-1985 and found a negative relationship between growth in production and unemployment. The Okun's coefficient is around -0.30 . 
Aghion and Howitt (1992) analyzed 20 OECD countries and 1974-1989 period with cointegration analysis. They found an inverse relationship between unemployment rate and growth.

Barreto and Howland (1993) analyzed the 1953- 1982 period in Japan with regression estimation. As a result of analyze, it is stated that the coefficients accepted in Okun's are not valid for the Japanese economy.

Weber (1995) considered the 1948-1988 period for the US economy in three different periods. Results that support the Okun's coefficient have been reached.

Moosa (1997) examined the 1960-1995 period in his study for the G-7 countries. The coefficient is the highest for North America, the lowest for Japan.

Attfield and Silverstone (1998) were studied of the relationship between output level and unemployment rate by co-integration method, the Okun's coefficient for the US economy was found to be -2.25 .

Moosa (1999) studied, the Okun's coefficient was examined for the US economy. Quarterly data from 1947Q1-1992Q2 were used and the Okun's coefficient was found to be approximately -0.38.

Lee (2000) conducted an analysis of 16 OECD countries. As a result of the analysis, it is concluded that there is cointegration between unemployment and growth variables.

Zonzilos (2000) has investigated the relationship between economic growth and unemployment for Greece from 1965 to 1999 . The results show, if output increases by $1 \%$ unemployment will decrease. The coefficient was found $0.28 \%$.

Freeman (2001) investigated Okun's law for the US national level and 8 regions. For the study, he used the 1958-1998 quarterly and 1977-1997 annual data. It has been found that the Okun's coefficient is constant and takes about two values between the regions.

Harris and Silverstone (2001) have analyzed unemployment and output levels relation. In this study, seven OECD countries were discussed. Empirical evidences show that there is no long-run relationship between two variables.

Anton Muscatelli and Tirelli (2001) have examined the unemployment and growth relationship for the OECD countries, over the period 1955-1990, using the structural VAR model, and found a negative relationship these variables.

Virén (2001), in his study for OECD countries over the period 1960-1997, determined that growth rate affected the unemployment negatively when the economic growth rate was above the long-term average growth rate.

Garavito (2002) found a negative relation between two macroeconomic variables - economic growth and unemployment rate - for Peru. The coefficient was estimated about 0.085 .

Apergis and Rezitis (2003) estimated the Okun's coefficient for certain regions of Greece over the period 1960-1997.The results reveal that Okun's relation has a structural variation in 1981. After 1981, unemployment is less responsive to changes in production in all regions.

Zagler (2003) investigated the Okun's Law using the VECM including France, Germany, Italy, the UK respectively. As a result, he stated that there is a co-integration between economic growth and unemployment in the long run and that there is a positive relationship between these variables.

Dimitris K. Christopoulos (2004) examined the Greek economy with Unit Root, Cointegration and Panel Data Analysis. According to empirical results; Okun's Law was confirmed at 6 out of 13 regions examined.

Semmler and Zhang (2005) state that the theory that the increase in growth is reducing unemployment is valid for most of the countries. 
Yilmaz (2005) found that there was no bi-directional causal relationship between economic growth and unemployment for the years 1978-2004 in the study of the Turkish economy. It is revealed that there is a unidirectional causality relation from unemployment to growth.

Knotek II (2007) tested the United States for the period 1948-2007 with Cointegration Analysis. The validity of Okun's law has been tested in the study. Coefficients found in the predicted regression confirm the coefficients determined in the original Okun's law.

Knotek (2007) updated Okun's study covering the period 1948-1960. The results are that it supports Okun.

Marinkov and Geldenhuys (2007) calculates Okun's coeffient for South Africa over 1970-2005. The results indicate that the Okun Law for South Africa is valid.

Fouquau (2008) could not identify a linear relationship for the twenty OECD countries for the period 1970-2004.

Lin (2008) investigates the relationship between unemployment and economic growth using a smooth-time-varying-parameter approach in their study of the US economy. According to their findings, the Okun's coefficient for the US was negative and thus the Okun's Law was guaranteed.

Dritsaki and Dritsakis (2009) estimate the Okun's coefficient for the Mediterranean countries. In the study conducted for the periods 1961-2002, the Okun's coefficient is -0.024 for Italy and -0.007 for Greece. The Italian coefficient represents the larger coefficient while the Greek coefficient represents the smaller coefficient.

Villaverde and Maza (2009) used panel data analysis for Spain and seventeen areas to examine the Okun's coefficient using data from 1980 to 2004 annually. The findings show that there is a contrary relationship between unemployment and output in many area and country-wide. Nevertheless, they found that the Okun's coefficient changes according to the region.

Andrei et al. (2009) tested the validity of the Okun's Law for Romania. There is a negative relationship between unemployment and growth.

Lal et al. (2010) have shown the existence of both long-term and short-term relationships between economic growth and unemployment in Bangladesh, China, India, Pakistan, Sri Lankan economies in the 1980-2006 period.

Kitov (2011) investigated the relationship between employment and real GDP per capita in his study of the US, France, UK, Australia, Canada and Spain economies. As a result of this study, Kitov (2011) has found that high unemployment figures are affected by low growth rates.

Kreishan (2011) reviewed the relationship between economic growth and unemployment for the Jordanian economy. Kreishan (2011) estimated the Okun's coefficient for the period 1970-2008. As a result of the analysis, it is stated that the Okun's Law is not valid for the Jordian economy.

Al-Habees and Abu Rumman (2012) investigated the relation between growth and unemployment for the Jordanian economy and several Arabic countries. The findings show that there is a strongly positive tendency to the high growth rates.

Fatai and Bankole (2013) have dealt with Okun's Law for the Nigerian economy within the period of 1980-2008. Empirical results show that the Okun's Law is not valid for the Nigerian economy.

Akram, Hussein and Raza (2014) have analyzed whether the law of Okinawan is valid for the Pakistan economy. In the study for the period of 1972-2012, they reached the conclusion that the Okun's Law for the Pakistan economy is not valid.

Lozanoska and Dzambaska (2014) examined the relationship between economic growth and unemployment for the Macedonian economy. Lozanoska and Dzambaska (2014),for the period of 20052012, stated that Okun's Law is not important for the Macedonian economy. 
Phiri (2014) study for the countries of South Africa covering the period of 2000-2013, revealed nonlineer equilibrium between economic growth and unemployment. To do this, a momentum threshold autoregressive model was used.

Makun and Azu (2015) analyzed the relationship between economic growth and unemployment for the Fiji economy over the years 1982-2012. A long-run relationship between economic growth and unemployment has been identified as a result of the analysis.

Ruxandra (2015) examined the relationship between economic growth and unemployment for the post-2007 period. It has been determined that Okun's Law is valid for the Romanian economy.

Apart from investigating the existence of the relationship between output level and unemployment rate, another discussion in the literature concerns whether there is an asymmetry in relation to outputunemployment.

Palley (1993) focuses on factors such as sectoral growth rate differentials and labor force participation rates.

In the United States, the results have confirmed the existence of an asymmetric relationship.

Virén (2001) also revealed asymmetry in his study on OECD countries. Virén (2001) stated that the reaction of unemployment to output changes differs from the contraction period during the conjuncture recovery period.

Ceylan and Şahin (2010) investigated whether the Okun's relationship for the Turkish economy is symmetric in their studies using annual data from 1950 to 2007. In order to test the asymmetric relation, co-integration analysis including TAR and M-TAR models is used. A result of the study show that the Okun's law in the Turkish economy is valid in long-term and the relationship is asymmetric.

\section{METHODOLOGY}

The panel consists of a combination of time series and horizontal section data. The panel is derived from a horizontal cross-sectional datum that repeats the samples over time; but here the same economic unit is followed during the sampling period.

In the study, the relationship between economic growth and unemployment in the Eastern European countries was examined for the period 1992-2014. The logarithms of the data were taken and unemployment throughout the study was expressed as Lnunemployment and economic growth Lngdp.

The data set taken from World Bank and consists of growth and unemployment rates of the 8 countries of Eastern Europe (Belarus, Bulgaria, Czech Republic, Romania, Poland, Ukraine, Hungary and Slovakia) between 1992-2014 years.

When the unemployment rates of the countries are analyzed by years, it is seen that Belarus's unemployment rate is $6.6 \%$ in 2002, Bulgaria's 21.4 in 1993, Czech Republic's $8.8 \%$ in 2000, Romania's 8.6\% in 1992, Poland's 19.9\% in 2002, Ukraine's 11.6\% in 1999 and 2000, Hungary's 12.1\% in 1993 and Slovakia's $19.3 \%$ in 2001 the highest unemployment rate has been reached. In addition, the lowest unemployment rates in these countries were found in Belarus in 2012 and 2014, Bulgaria in 2008, Czech Republic in 1993, Romania in 1997, Poland in 2008, Ukraine in 1995, Hungary in 2001 and Slovakia in 2008 respectively. 

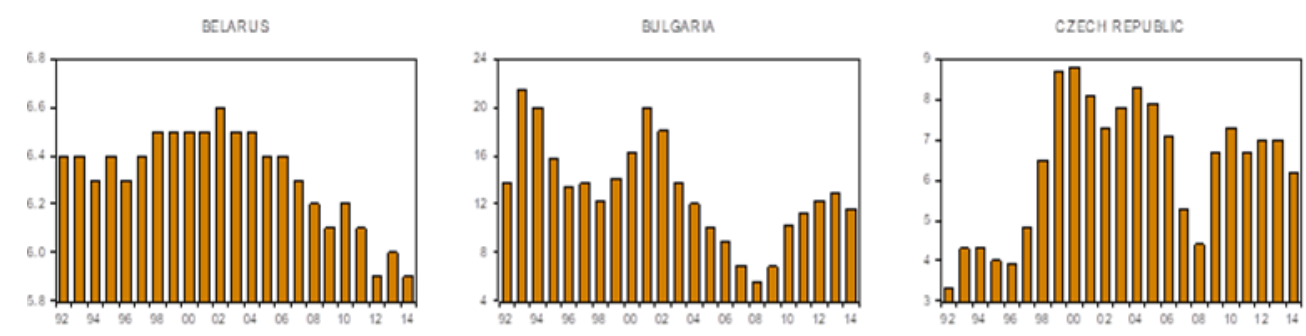

ROMANU

POUND
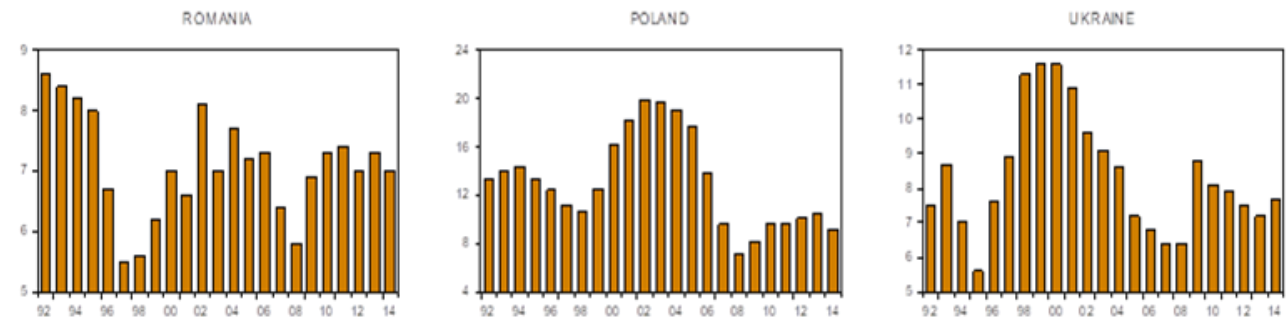

HUNGARY

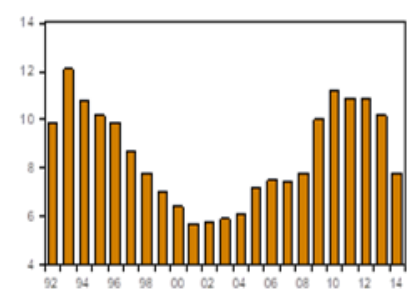

SLOVAKM

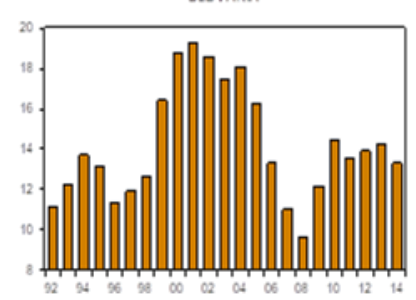

Figure 1. Unemployment Rates in Eastern European Countries

\section{EMPIRICAL RESULTS AND DISCUSSION}

\subsection{Panel Unit Root Tests}

When panel data is used to test the unit root, the horizontal section dependency must be tested. The first-generation panel unit root tests are divided into two groups according to the unchanging and changing state of the unit $\varrho$. these two groups are called first group tests and second group tests.

The Levin, Lin and Chu (LLC.) (2002) test in the first group considers individual constants and time trends. Levin, Lin and Chu (2002) calculated the standard deviation of the panel unit root test by the ratio of the long-term standard deviation to the short-term standard deviation in the horizontal section. The calculated standard deviations are used to calculate the corrected t statistics.

Im, Pesaran and Shin (IPS.) (2003) panel unit root test is the second group panel unit root tests In the Im, Pesaran and Shin (2003) test, hetoregion is allowed between the units in the panel.

The relationship between unemployment and growth in eastern European countries has been shown in two different tables, with the help of panel unit root.

In this study, a panel unit root test was applied to control if the series are stationary or not. In this context LLC, IPS, ADF and PP tests a hypothesis based, as opposite for the choice of the alternative hypothesis that there is unit root, in other words the data is stationary. Within this framework, it is determined that the data are non-stationary at the level. For this reason differences were taken. After this step, economic growth and unemployment were found to be stationary in first differences.

Table 1 represents that economic growth and unemployment series non-stationary at the level. 
Panel Unit Root Test Results

\begin{tabular}{|l|c|c|c|c|}
\hline Variable & \multicolumn{2}{|c|}{ Log unemployment (level) } & \multicolumn{2}{c|}{ Log economic growth (level) } \\
\hline Method & Stat. & Prob. & Stat. & Prob. \\
\hline $\begin{array}{l}\text { Levin, Lin \& } \\
\text { Chu }\end{array}$ & -1.55269 & 0.0602 & -1.27617 & 0.1009 \\
\hline IPS Stat. & -1.74821 & 0.0402 & 1.83492 & 0.9667 \\
\hline $\begin{array}{l}\text { ADF - } \\
\begin{array}{l}\text { Fisher Chi- } \\
\text { Square }\end{array}\end{array}$ & 28.5370 & 0.0273 & 5.40983 & 0.9933 \\
\hline $\begin{array}{l}\text { PP - Fisher } \\
\text { Chi-Square }\end{array}$ & 17.3228 & 0.3650 & 4.92435 & 0.9961 \\
\hline
\end{tabular}

Table 2 represents that economic growth and unemployment series stationary at first differences.

Panel Unit Root Results

\begin{tabular}{|l|c|c|c|c|}
\hline Variable & \multicolumn{2}{|c|}{$\Delta$ log unemployment } & \multicolumn{2}{c|}{$\Delta$ log economic growth } \\
\hline Method & Stat. & Prob. & -4.45974 & 0.0000 \\
\hline $\begin{array}{l}\text { Levin, Lin \& } \\
\text { Chu }\end{array}$ & -3.35975 & 0.0004 & -3.61971 & 0.0001 \\
\hline IPS Stat. & -4.35312 & 0.0000 & 40.2253 & 0.0007 \\
\hline $\begin{array}{l}\text { ADF - } \\
\begin{array}{l}\text { Fisher Chi- } \\
\text { Square }\end{array}\end{array} \quad 48.2711$ & 0.0000 & 62.5876 & 0.0000 \\
\hline $\begin{array}{l}\text { PP - Fisher } \\
\text { Chi-Square }\end{array}$ & 70.1194 & 0.0000 & & \\
\hline
\end{tabular}

The two tables shown above have examined the economic growth and unemployment relationship of Eastern European Countries with the help of some panel unit root tests. According to the results the series are stationary at first differences.

\subsection{Pooled OLS Estimation}

In this study Pooled OLS analysis method was used and the findings are shown in table 3.

One of the assumptions based on the estimation results that the pooled least squares model is presented is that there is no difference between horizontal $(\mathrm{N})$ data matrices. the model predicts a common fixed term for all horizontal sections (Asteriou, 2006).

The pooled OLS regression analysis method provides more information than the one-time crosssectional analyzes because it uses the average value of the time-series of the variables.

The panel regression equation in the study is as follows.

$$
\ln U N E M P i=\beta 0+\beta 1 \ln G D P i
$$

Where UNEMPi is the unemployment rate of country $\mathrm{i}$ 
GDPi is the gross domestic product of country $i$

The results are as follows:

$$
\ln U N E M P=4.42-0.089 \ln G D P i
$$

Pooled OLS Results

\begin{tabular}{|c|c|c|c|c|}
\hline Variable & Coefficient & Std.Error & t-stat. & Prob. \\
\hline $\operatorname{lnGDP}$ & -0.089781 & 0.004642 & -19.34087 & 0.0000 \\
\hline Cons. & 4.423639 & 0.115615 & 38.26191 & 0.0000 \\
\hline \multicolumn{5}{|c|}{ Random Effects (cross) } \\
\hline Belarus & -0.427512 & & & \\
\hline Bulgaria & 0.238340 & & & \\
\hline Czech Rep. & -0.338933 & & & \\
\hline Romania & -0.225342 & & & \\
\hline Poland & 0.459961 & & & \\
\hline Ukraine & -0.072029 & & & \\
\hline Hungary & -0.049588 & & & \\
\hline Slovakia & 0.415102 & & & \\
\hline $\mathrm{R}^{2}$ & 0.976252 & $\begin{array}{c}\text { Mean Dependent } \\
\text { var. }\end{array}$ & & 25.85604 \\
\hline Adj. $\mathrm{R}^{2}$ & 0.975166 & $\begin{array}{l}\text { S.D. Dependent } \\
\text { var. }\end{array}$ & & 46.11433 \\
\hline S.E of regression & 1.020671 & SSR & & 182.3097 \\
\hline SSR & 9.036106 & DW- Stat. & & 1.039217 \\
\hline F-stat & 899.2383 & & & \\
\hline Prob (F-stat) & 0.000000 & & & \\
\hline
\end{tabular}

The results of POLS test were statistically significant at the level of 5\%. The finding of R-square at 0.9762 shows us that about 98 percent changing in the total unemployment rate are explained by explanatory and exogenous variables. As a result of the test, the coefficient of GDP was found negative and significant at the $5 \%$ which means that $1 \%$ rise in GDP will fall unemployment rate by $0.08 \%$.

\subsection{The Panel Co-integration Test}

Pedroni proposed a test that allowed heterogeneity in the cointegration vector in cointegration analyzes in 1997, 1999, 2000 and 2004 (Asteriou and Hall, 2007). This test not only allows dynamic and stationary effects to be different between the cross-sections of the panel, but also permits differentiation of the cross-section of the cube under the alternative hypothesis (Güvenek ve Alptekin, 2010).

Pedroni tests have some positive features in Pedroni's approach, which differs from McCoskey's and Kao's approaches in terms of cross-sectional hypothetical trends and zero hypotheses where there is no cointegration. Pedroni tests allow multiple explanatory variables. The cointegration vector varies along different parts of the panel. Errors allow for heterogeneity across cross-sectional units. All these are expressed as positive features. 
It is investigated by cointegration analyzes whether there is a stationary relationship between nonstationary series the Pedroni cointegration analysis was used to study the long-term bilateral relationship between economic growth and unemployment.

Panel co-integration test developed by Pedroni (2004) was applied to determine co-integration between the series. In this context, Pedroni has developed seven test statistics to determine whether cointegration exists between panel data. These tests are divided into two different categories. The first category contains four tests pooled "within" dimension. The second category includes three other tests in the "between" dimension (Asteriou and Hall, 2007). The first three of the four tests in the first category are non-parametric tests. The first test is a statistic in the type of variance ratio. The second is PhillipsPeron (PP) (rho) statistic, The third statistic is similar to the PP (t) statistic. The fourth statistic is a parametric statistic similar to the Augmented Dickey Fuller (ADF) (t) statistic. In the second category, the three tests are similar to the PP (rho) statistic, while the other two are similar to the PP (t) and ADF (t) statistics.

The null hypothesis of tests is "there is no co-integration between the series of panel data." As a result of the test, it was seen that the series are co-integrated. So it can be clearly said that the series are moving together in a long term period.

Table 4

The Panel Co-integration Test Results

\begin{tabular}{|l|l|l|l|}
\hline & & T-Stat. & Probability Value \\
\hline \multirow{4}{*}{ Pedroni } & Panel v-Stat. & 4.282422 & 0.0000 \\
\cline { 2 - 4 } & Panel rho-Stat. & -5.454062 & 0.0000 \\
\cline { 2 - 4 } & Panel PP-Stat. & -6.014867 & 0.0000 \\
\cline { 2 - 4 } & Panel ADF-Stat. & -4.416878 & 0.0000 \\
\cline { 2 - 4 } & Group rho-Stat. & -4.071289 & 0.0000 \\
\cline { 2 - 4 } & Group PP-Stat. & -6.690520 & 0.0000 \\
\cline { 2 - 4 } & Group ADF-Stat. & -4.449837 & 0.0000 \\
\hline
\end{tabular}

The concepts of unemployment and growth are important both in terms of economic and social policy makers. Economic growth represents the most essential indicator of achieving macroeconomic targets for all developed and developing countries. The concept of unemployment is a very important indicator in terms of social indicators. These variables are important in that they have the power to influence economic and social life.

The problem of unemployment continues to exist both in developed and developing countries as a global problem. The solution of the long-term unemployment problem, which is an economic and social reflection, is possible by determining the national employment policies that are appropriate to the country facts without considering the globalization situation, considering the information society requirements and technological developments and changes.

In a country where economic growth is increasing, it is expected that the labor force used to carry out this production will increase and as a result the unemployment rates will decrease (Eser, 2014). Okun's Law reveals that there is an inverse relationship between unemployment rates and economic growth. In the literature, it is generally concluded that the results are consistent with the Okun Law, and that only the coefficient can differ from country to country.

Most of the countries in the study are the developing countries in 2017 according to the international statistical institute (ISI) bank classification. This type of countries should be expected to increase their 
growth targets, ensure income justice, increase national income per capita and reduce unemployment. From this point of view, the results of the POLS test and co-integration test in the study are accord with the literature. Based on the long-term movement of unemployment and growth rate data, it can be assumed that an increase in growth can be seen by setting unemployment-reducing measures.

\section{CONCLUSION}

The main target of this paper is to analyze the relation between unemployment and growth according to Okun's Law. In the study, unemployment and growth rates of the Eastern European countries from 1992 to 2014 were analyzed by panel data method.

In this paper, panel unit root test was applied and it is understood that series are not stationary at level. For this reason the first differences of the series have been taken. After this phase, panel OLS was tested and it was determined that $1 \%$ rise in GDP will fall the unemployment rate by $0.08 \%$. Finally, our data sets were tested by using co-integration test and found that there is a co-integration between unemployment and growth.

\section{REFERENCES}

Aghion, P. ve Howitt,P. (1990). A Model of Growth Through Creative Destruction. Econometrica, 60, 323-351.

Akram, M., Hussain, S., Raza, S. H., \& Masood, S. (2014). An empirical estimation of Okun's Law in context of Pakistan. Journal of Finance and Economics, 2(5), 173-177. Retrieved from https://www.researchgate.net/publication/270608121 An Empirical Estimation of Okun'S Law in Cont ext of Pakistan.

Al-Habees, M. A., \& Rumman, M. A. (2012). The relationship between unemployment and economic growth in Jordan and some Arab countries. World Applied Sciences Journal, 18(5), 673-680.

Andrei, D. B., Vasile, D., \& Adrian, E. (2009). The correlation between unemployment and real GDP growth. A study case on Romania. Analele Unversitătı Din Oradea, 316.

Anton Muscatelli, V., \& Tirelli, P. (2001). Unemployment and growth: some empirical evidence from structural time series models. Applied Economics, 33(8), 1083-1088. Retrieved from http://www.tandfonline.com/doi/abs/10.1080/00036840010003276.

Apergis, N., \& Rezitis, A. (2003). An examination of Okun's law: evidence from regional areas in Greece. Applied Economics, 35(10), 1147-1151. Retrieved from http://www.tandfonline.com/doi/pdf/10.1080/0003684032000066787.

Arrow, K. (1962). Economic welfare and the allocation of resources for invention. In The rate and direction of inventive activity: Economic and social factors (pp. 609-626). Princeton University Press.

Asteriou, D., \& Hall, S. G. (2007). Applied Econometrics: a modern approach, revised edition. Hampshire: Palgrave Macmillan.

Asteriou, D., \& Stephen, G. Hall 2007 Applied Econometrics: A Modern Approach Using Eviews and Microfit (Revised Edition).

Attfield, C. L., \& Silverstone, B. (1998). Okun's law, cointegration and gap variables. Journal of Macroeconomics, 20(3), 625-637. Retrieved from https://doi.org/10.1016/S0164-0704(98)00076-7.

Barreto, H., \& Howland, F. (1993). There are two Okun's law relationships between output and unemployment. Crawfordsville, Wabash College.

Ceylan, S., \& Sahin, B. Y. (2010). Asymmetry in the Erlationship Between Unemployment and Economic Growth. Dogus University Journal, 11(2), 157-165. Retrieved from http://journal.dogus.edu.tr/index.php/duj/article/view/15.

Christopoulos, D. K. (2004). The relationship between output and unemployment: Evidence from Greek regions. Papers in Regional Science, 83(3), 611-620. doi.10.1111/j.1435-5597.2004.tb01928. 
Dritsaki, C., \& Dritsakis, N. (2009). Okun's coefficient for four Mediterranean member countries of EU: an empirical study. International Journal of Business and Management, 4(5), 18. doi: http://dx.doi.org/10.5539/ijbm.v4n5p18.

Ercan, N. Y. (2000). İçsel Büyüme Teorisi: Genel Bir Bakış. Planlama Dergisi Özel Sayı-DPT'nin Kuruluşunun 42. Yılı.

Eser, B. Y. (2014). Ekonomik Büyüme ve İşsizlik İlişkisi: Türkiye Örneği. TISK Academy/TISK Akademi, 9(18). http://www.tisk.org.tr/akademi.asp.

Evans, G. W. (1989). Output and unemployment dynamics in the United States: 1950-1985. Journal of Applied Econometrics, 4(3), 213-237. DOI: 10.1002/jae.3950040302.

Fatai, B. O., \& Bankole, A. (2013). Empirical test of Okun's Law in Nigeria. International Journal of Economic Practices and Theories, 3(3), 227-231. Retrieved from http://ijept.org/index.php/ijept/article/view/Empirical Test of Okun Law in Nigeria.

Fouquau, J. (2008). Threshold effects in Okun's law: a panel data analysis. Economics Bulletin, $5,1$. https://halshs.archives-ouvertes.fr/hal-00565477/document.

Freeman, D. G. (2001). Panel tests of Okun's law for ten industrial countries. Economic Inquiry, 39(4), 511-523. doi:10.1093/ei/39.4.511.

Garavito, C. (2002). La ley de Okun en el Perú: 1970-2000. Pontificia Universidad Católica Del Perú, Departamento De Economia. [PDF] 184.168.109.199.

Güvenek, B., \& Alptekin, V. (2010). Energy Consumption And Economic Growth: A Panel Data Analyses for Oecd Countries. Enerji, Piyasa Ve Düzenleme, 1(2), 172-193.

Harris, R., \& Silverstone, B. (2001). Testing for asymmetry in Okun's law: A cross-country comparison. Economics Bulletin, 5(2), 1-13. Retrieved from http://www.economicsbulletin.com/2001/volume5/EB-01E00001A.pdf.

Holmes, M. J., \& Silverstone, B. (2006). Okun's law, asymmetries and jobless recoveries in the United States: A Markov-switching approach. Economics Letters, 92(2), 293-299. https://doi.org/10.1016/j.econlet.2006.03.006.

Im, K. S., Pesaran, M. H., \& Shin, Y. (2003). Testing for unit roots in heterogeneous panels. Journal of econometrics, 115(1), 53-74. Retrieved from https://doi.org/10.1016/S0304-4076(03)00092-7.

Kitov, I. (2011). Okun's law revisited: Is there structural unemployment in developed countries?. http://dx.doi.org/10.2139/ssrn.1883003.

Knotek II, E. S. (2007). How useful is Okun's law?. Economic Review-Federal Reserve Bank of Kansas City, $92(4), 73$.

Kreishan, F. M. (2011). Economic growth and unemployment: An empirical analysis. Journal of Social Sciences, 7(2), 228-231.

Lal, I., Muhammad, S. D., Jalil, M. A., \& Hussain, A. (2010). Test of Okun's law in some Asian countries cointegration approach. Journal of Scientific Research, 40(1), 73-80. doi: http://dx.doi.org/10.2139/ssrn.1562602.

Lee, J. (2000). The robustness of Okun's law: Evidence from OECD countries. Journal of macroeconomics, 22(2), 331356. doi: https://doi.org/10.1016/S0164-0704(00)00135-X.

Levin, A., Lin, C. F., \& Chu, C. S. J. (2002). Unit root tests in panel data: asymptotic and finite-sample properties. Journal of econometrics, 108(1), 1-24. Retrieved from https://doi.org/10.1016/S0304-4076(01)000987.

Lin, S. C. (2008). Smooth-time-varying Okun's coefficients. Economic Modelling, 25(2), 363-375. doi: https://doi.org/10.1016/j.econmod.2007.06.009.

Lozanoska, A., \& Dzambaska, E. (2014). Economic Growth And Unemployment: An Empirical Analysis (A Case Study On The Republic Of Macedonia). Economic Development/Ekonomiski Razvoj, 16(3). Retrieved from https://www.ceeol.com/search/article-detail?id=59654.

Lucas, R. E. (1988). On the mechanics of economic development. Journal of monetary economics, 22(1), 3-42. doi: https://doi.org/10.1016/0304-3932(88)90168-7.

Makun, K., \& Azu, N. P. (2015). Economic Growth And Unemployment In Fiji: A Cointegration Analysis. International Journal of Development and Economic Sustainability, 3(4), 49-60.

Marinkov, M., \& Geldenhuys, J. P. (2007). Cyclical unemployment and cyclical output: An estimation of Okun's coefficient for South Africa. South African Journal of Economics, 75(3), 373-390. doi:10.1111/j.18136982.2007.00134. 
Moosa, I. A. (1997). A cross-country comparison of Okun's coefficient. Journal of Comparative Economics, 24(3), 335356. doi: https://doi.org/10.1006/jcec.1997.1433.

Moosa, I. A. (1999). Cyclical output, cyclical unemployment, and Okun's coefficient A structural time series approach. International Review of Economics \& Finance, 8(3), 293-304. doi: https://doi.org/10.1016/S10590560(99)00028-3.

Okun, A. M. (1963). Potential GNP: its measurement and significance (pp. 98-103). Yale University, Cowles Foundation for Research in Economics.

Palley, T. I. (1993). Okun's Law and the asymmetric and changing cyclical behaviour of the USA economy. International Review of Applied Economics, 7(2), 144-162. doi: http://dx.doi.org/10.1080/758530144.

Pedroni, P. (2004). Panel cointegration: asymptotic and finite sample properties of pooled time series tests with an application to the PPP hypothesis. Econometric theory, 20(3), 597-625. doi: https://doi.org/10.1017/S0266466604203073.

Phiri, A. (2014). Nonlinear co-integration between unemployment and economic growth in South Africa. Managing Global Transitions, 12(4), 303.

Romer, P. M. (1986). Increasing returns and long-run growth. Journal of political economy, 94(5), 1002-1037. doi: https://doi.org/10.1086/261420.

Ruxandra, P. (2015). The Specifics Of Okun'S Law In The Romanian Economy Between 2007 And 2013. AnnalsEconomy Series, 1, 50-53.

Semmler, W., \& Zhang, W. (2005). The impact of output growth, labor market institutions, and macro policies on unemployment. Working paper, SCEPA.

Shaw, G. K. (1992). Policy implications of endogenous growth theory. The Economic Journal, 102(412), 611-621. DOI: $10.2307 / 2234298$.

Solow, R. M. (1956). A contribution to the theory of economic growth. The quarterly journal of economics, 70(1), 65-94.

Solow, R. M. (1956). A contribution to the theory of economic growth. The quarterly journal of economics, 70(1), 65-94. doi: https://doi.org/10.2307/1884513.

Villaverde, J., \& Maza, A. (2009). The robustness of Okun's law in Spain, 1980-2004: Regional evidence. Journal of Policy Modeling, 31(2), 289-297. doi: https://doi.org/10.1016/j.jpolmod.2008.09.003.

Virén, M. (2001). The Okun curve is non-linear. Economics letters, 70(2), 253-257. doi: https://doi.org/10.1016/S01651765(00)00370-0.

Weber, C. E. (1995). Cyclical output, cyclical unemployment, and Okun's coefficient: A new approach. Journal of applied econometrics, 10(4), 433-445. doi:10.1002/jae.3950100407.

Yilmaz, Ö. G. (2005). Türkiye ekonomisinde büyüme ile işsizlik oranları arasındaki nedensellik ilişkisi. Ekonometri ve İstatistike e-Dergisi, (2), 63-76.

Zagler, M. (2003). The Dynamics of Economic Growth and Unemployment in Major European Countries: Analysis of Okun' s Law. Applied Econometrics and International Development, 3(3). Retrieved from http://www.usc.es/economet/reviews/aeid336.pdf.

Zonzilos, N. 2000. The Philips Curve Of Greek Economy And The Time Variant Nairu. Economic Bulletin in Greek, $15,15-31$ 